\title{
IMPLEMENTASI KEBIJAKAN REKTOR TENTANG TATA KRAMA DAN ETIKA MAHASISWA DI UKM/ORMAWA UNIVERSITAS NEGERI PADANG
}

\author{
Nillam Martha Sonia Ningrum \\ Ilmu Administrasi Publik, Fakultas Ilmu Sosial, Universitas Negeri Padang, nillammarthasn@gmail.com
}

\author{
Afriva Khaidir \\ Ilmu Administrasi Publik, Fakultas Ilmu Sosial, Universitas Negeri Padang, afrivak@yahoo.com
}

Zikri Alhadi

Ilmu Administrasi Publik, Fakultas Ilmu Sosial, Universitas Negeri Padang, the_zikral@yahoo.co.id

\begin{abstract}
Abstrak
Penelitian ini bertujuan untuk mengetahui impelementasi kebijakan Rektor tentang tata krama dan etika mahasiswa di UKM/Ormawa Universitas Negeri Padang berdasarkan Surat Edaran Nomor 3916/UN35/KM/2017. Latar belakang dilakukannya penelitian ini karena masih ada beberapa point dalam surat edaran yang tidak terlaksana seperti kegiatan mahasiswa hingga malam hari, menjadikan sekretariat sebagai tempat tidur, serta keamanan dan kebersihan PKM yang belum terjaga. Penelitian ini merupakan penelitian kualitatif dengan menggunakan metode deskriptif. Informan penelitian ini yaitu Wakil Rektor III UNP selaku pembuat SE No.3916/UN35/KM/2017, Wakil Dekan III Fakultas Ilmu Sosial, Kabag. Kemahasiswaan dan Alumni, Kasubbag. Kemahasiswaan MPIK, Pembina UKM, Satpam, BEM dan MPM, beberapa pengurus UKM/Ormawa selingkungan UNP, mahasiswa dan masyarakat yang tinggal disekitar UNP yang dapat memberikan informasi. Teknik dan alat pengumpulan data dalam penelitian ini menggunakan teknik wawancara, observasi dan studi dokumentasi. Dalam pengumpulan data digunakan instrumen penelitian berupa pedoman wawancara, format observasi dan format studi dokumentasi. Dalam penelitian ini data yang dianalisis diperoleh dari wawancara dan diinterpretasikan secara kualitatif, berupa abstraksi, kata-kata dan pernyataan. Hasil penelitian menunjukkan bahwa implementasi kebijakan Rektor tentang tata krama dan etika mahasiswa di UKM/Ormawa UNP belum berjalan sebagaimana mestinya karena masih ada beberapa point dalam SE tersebut yang tidak terlaksana. Adapun yang menjadi faktor pendukung pelaksanaan SE No.3916/UN35/KM/2017 antara lain faktor komunikasi dan struktur organisasi, sedangkan disposisi(sikap), sumber daya, dan komunikasi menjadi faktor penghambat implementasi kebijakan Rektor tersebut. Dari hasil penelitian ini, peneliti memberikan saran kepada pihakpihak yang terlibat, diantaranya kepada Rektor UNP selaku pembuat kebijakan agar menjaga komunikasi, koordinasi dan kerjasama yang baik dengan setiap elemen, dan untuk pelaksanaan kebijakan dengan tegas perlu aturan hukum yang lebih kuat daripada surat edaran, begitu juga dengan mahasiswa dan UKM/Ormawa harus ada pemahaman dan kesadaran terhadap peraturan yang ada agar lebih peka terhadap suatu kebijakan sehingga implementasi kebijakan Rektor bisa berjalan maksimal.
\end{abstract}

Kata Kunci: Kebijakan Publik, Tata Krama dan Etika Mahasiswa, UKM/Ormawa

\begin{abstract}
This study aims to determine the implementation of Rector's policy on student's etiquette and ethics in Student Activity Units or Student Organization (UKM/Ormawa) Padang State University (UNP) based on Circular Letter Number 3916/UN35/KM/2017. The background of this research because there are still some points in the circular that did not happen like the activities of students until the night, making the secretariat as a place to sleep, and the safety and cleanliness of PKM that has not been awake. This research is a qualitative research using descriptive method. The informant of this research is Vice Rector III UNP as the maker of SE No.3916/UN35/KM/2017, Vice Dean III Faculty of Social Sciences, Kabag. Student Affairs and alumnus, Kasubbag. MPIK's Student Affairs, UKM Coach, Security Guard, BEM and MPM, some UKM/Ormawa managers UNP environment, students and communities living around UNP who can provide information. Techniques and data collection tools in this study using interview techniques, observation and documentation studies. In the data collection used research instruments in the form of interview guides, observation format and documentation study format. In this study the data analyzed obtained from interviews and interpreted qualitatively, in the form of abstraction, words and statements. The result of the research shows that the implementation of Rector's policy on students' etiquette and ethics in UKM/Ormawa UNP is good enough with the form of control that is done related to the etiquette and ethics in the student organization at UNP only still need improvement on the policy that
\end{abstract}


has been implemented. Constraints encountered in the implementation of SE No.3916/UN35/KM/2017, among others, still low understanding and awareness of the contents of the policy, facilities and infrastructure are still inadequate, less assertive sanctions given to violators and still lack of supervision from the Rector and other related parties. From the results of this study the researchers provide advice to the parties involved, including to the Rector of UNP as policy makers maintain communication, coordination and good cooperation with each element, and for the implementation of the policy firmly need a rule of law is stronger than the circular, so also with the students and coaches UKM/Ormawa Coach to always direct and supervise the activities of students to be more directed and orderly. In addition, there must be full security and supervision from the security guard and the community around UNP, as well as students and UKM/Ormawa there must be understanding and awareness of existing regulations to be more sensitive to a policy so that the implementation of Rector policy can run optimally.

Keywords: Public Policy, Menners and Etics, UKM/Ormawa

\section{PENDAHULUAN}

Pergeseran paradigma Perguruan Tinggi yang fokus pada proses, pembelajaran berpusat pada mahasiswa, dosen bertindak sebagai fasilitator dan penekanan pada cara menyelesaikan permasalahan menuntut mahasiswa untuk menjadi lokomotif, bersikap aktif, kreatif dan inovatif serta mampu berkreasi. Selain itu, adanya pergeseran dalam lingkungan global tersebut menuntut setiap universitas untuk melakukan perubahan. Untuk melangkah ke arah yang lebih berkualitas melalui kesempatan otonomi diharapkan perguruan tinggi dapat mengatur diri sendiri, menentukan arah dan kebijakan untuk mencapai tujuan yang telah ditetapkan agar dapat menjadi institusi perguruan tinggi yang lambat laun dapat bersaing dalam persaingan global melalui keunggulan sumber daya manusia (SDM), hasil riset dan temuan lainnya. Dalam rangka meningkatkan daya saing bangsa, maka kualitas SDM harus ditingkatkan agar menjadi lulusan yang berkompeten. Lulusan yang kompeten tidak hanya sekedar mampu menguasai pengetahuan dan teknologi di bidangnya (kemampuan akademik), melainkan juga memiliki soft skills dalam bentuk keterampilan bersikap dan berprilaku. Salah satu wadah bagi mahasiswa untuk belajar berorganisasi dan mengembangkan soft skills yaitu dengan organisasi kemahasiswaan.

Organisasi kemahasiswaan merupakan salah satu elemen yang sangat penting dalam proses pendidikan di perguruan tinggi. Hal ini tertuang pada Kepmendikbud No.155/U/1998 tentang Pedoman Umum Organisasi Kemahasiswaan di Perguruan Tinggi yang menyebutkan bahwa organisasi mahasiswa intra perguruan tinggi merupakan wahana dan sarana pengembangan diri mahasiswa ke arah perluasan wawasan dan peningkatan kecendekiawanan serta integritas kepribadian untuk mencapai tujuan pendidikan tinggi. Adapun salah satu tujuan perguruan tinggi yaitu mengembangkan potensi mahasiswa agar menjadi manusia yang beriman dan bertakwa kepada Tuhan Yang Maha Esa dan berakhlak mulia, sehat, berilmu, cakap, kreatif, mandiri, terampil, kompeten, dan berbudaya untuk kepentingan bangsa. Maka dari itu sebagai tempat untuk penyelenggaraan pendidikan, perguruan tinggi memiliki tugas dan tanggung jawab untuk meletakkan dasar-dasar nilai moral kepada mahasiswa untuk memiliki nilai sopan santun dan kebebasan yang bertanggung jawab baik dalam akademik maupun dalam organisasi mahasiswa.

Pengelolaan organisasi kemahasiswaan di dalam kampus (intra kampus) diatur oleh Surat Keputusan (SK) Menteri Pendidikan Nasional dan Kebudayaan No. 155/U/1998 tentang Pedoman Umum Organisasi Kemahasiswaan. Keputusan Menteri tersebut di masingmasing perguruan tinggi dijabarkan dan dituangkan dalam petunjuk teknis dengan surat keputusan Rektor. Di Universitas Negeri Padang (UNP) penjabaran SK Menteri tersebut disyahkan oleh Rektor, setelah sebelumnya dimusyawarahkan dan disepekati di lembaga mahasiswa tingkatan Universitas yakni Majelis Perwakilan Mahasiswa (MPM). Adapun tugas dan wewenang dari masing-masing jenis organisasi kemahasiswaan UNP telah dibuat dalam Keputusan Rektor No.55/J.41/KM/2004 tentang Petunjuk Teknis Organisasi Kemahasiswaan UNP.

Dalam melaksanakan kegiatan ekstrakurikuler, UNP memiliki beberapa Unit Kegiatan Mahasiswa (UKM) dengan berbagai macam kegiatan, visi dan misi. UKM hadir sebagai wadah untuk mengembangkan diri oleh mahasiswa dan untuk mahasiswa. UKM sangat identik dengan jam malam. Mulai dari subuh hingga subuh lagi, UKM tidak pernah sepi dari hiruk pikuk mahasiswa. Sebagian jam malam tersebut digunakan untuk mengadakan latihan, diskusi dan rapat untuk acara yang akan diadakan. Kegiatan ini dilakukan malam hari karena kalau siang mahasiswa tidak bisa berkumpul penuh diakibatkan jadwal kuliah yang padat (UNPku.com:2016).

Namun seringkali didapati mahasiswa yang masih berkegiatan hingga malam hari dan ada yang sampai menginap di sekretariat. Selain akan mengganggu ketertiban dan keamanan kampus, kegiatan kampus yang dilakukan hingga malam hari juga akan menimbulkan 
penilaian masyarakat sekitar terhadap tata krama dan etika mahasiswa di kampus. Untuk menyikapi hal ini, Rektor UNP mengeluarkan Surat Edaran dengan No.722/UN35/KM/2016 pada 17 Februari 2016 lalu yang kemudian diperbarui pada tanggal 30 Maret 2017 dengan No.3916/UN35/KM/2017. Sasarannya adalah mereka yang aktif dalam kegiatan kampus baik itu Ormawa maupun UKM. Enam poin tersebut berupa, Pertama, larangan berkegiatan ekstrakulikuler di kampus setelah pukul 18.00 WIB dan jika ada kegiatan diluar jam tersebut harus meminta izin terlebih dahulu kepada Pembina dan melapor kepada keamanaan UNP, Kedua, kegiatan diluar kampus harus mendapat izin dari WR3 dan WD3 bagi setiap fakultas/jurusan dan didampingi oleh Pembina, Ketiga, larangan menginap di sekretariat, Keempat, tidak terlibat dengan narkoba, miras, judi dan pergaulan bebas, Kelima, harus menjaga keamanan, ketertiban, kebersihan dan keindahan masing-masing sekretariat, dan Keenam, bagi yang melanggar diberi sanksi. Aturan ini semakin ditekankan seiring dengan gedung Pusat Kegiatan Mahasiswa (PKM) baru yang dialokasikan untuk UKM. Tujuannya adalah untuk mengeliminasi tindakan negatif, menjaga tata krama dan etika di kampus, serta mengelola kegiatan mahasiswa agar berjalan tertib dan aman.

Namun dalam prakteknya, peraturan ini tidak berjalan efektif hingga sekarang meskipun telah diperbarui. Kegiatan mahasiswa masih ada walaupun telah dibatasi waktunya. Begitu juga sekre yang dijadikan sebagai tempat tidur, kegiatan mahasiswa yang tidak memiliki izin dari Pembina dan tidak melapor kepada satpam, keamanan dan kebersihan yang belum terjaga, minimnya pengawasan dari penanggungjawab kegiatan mahasiswa di UKM/Ormawa, kurangnya sarana dan prasarana di PKM, dan adanya tindakan asusila serta perilaku menyimpang lainnya menjadi indikasi bahwa aturan ini belum terlaksana sebagaimana mestinya. Disisi lain, aturan ini menuai beberapa protes dari kalangan aktivis kampus. Mereka berpendapat ada beberapa poin dari surat edaran ini tidak sesuai dengan situasi dan kondisi seperti larangan pada poin pertama. Dengan adanya batasan jam ini, tentu membuat kegiatan organisasi mahasiswa menjadi terhambat (SKK Ganto UNP edisi 191:2016). Pro dan kontra ini juga menjadi salah satu penyebab tidak berjalan berjalan aturannya ini hingga sekarang.

Berdasarkan masalah yang melatarbelakangi penelitian ini, yang menjadi rumusan masalah adalah bagaimana implemetasi kebijakan Rektor tentang tata krama dan etika mahasiswa di UKM/Ormawa UNP dan apa faktor-faktor yang mempengaruhi implementasi kebijakan Rektor tentang tata krama dan etika mahasiswa di UKM/Ormawa UNP.
Penelitian tentang organisasi mahasiswa sudah pernah dilakukan.. Pertama; Mustika Cahyaning (2014), melihat bagaimana hubungan mahasiswa dengan organisasi dan apa pentingnya organisasi bagi kehidupan mahasiswa. Kesimpulan dari penelitiannya menyebutkan bahwa organisasi sangatlah erat dengan mahasiswa, adapun faktor yang mempengaruhi minat mahasiswa untuk berorganisasi di kampus yaitu ingin menambah pengalaman, memperbanyak teman, berkreasi dan beraktivitas lebih luas serta berinteraksi dengan orang lain. Kedua; Muhammad Ridwan (2016), beliau melakukan penelitian tentang implementasi good governance pada organisasi mahasiwa demi mewujudkan good student governance di Universitas Gadjah Mada (UGM) dengan melihat pelaksanaan beberapa prinsip good governance yang ada yaitu transparansi, akuntabilitas dan partisipasi. Kesimpulan dari penelitiannya menyebutkan bahwa prinsip transparansi, akuntabilitas dan partisipasi dalam organisasi mahasiswa belum terlaksana dengan baik di UGM sehingga perlu memperkuat pengaturan terhadap ketiga prinsip good governance dan meningkatkan kepedulian dan kepercayaan mahasiswa dalam organisasi mahasiswa, agar di dalam menerapkan good student governance menjadi efektif dan optimal. Ketiga; Suroto (2016), yang mengatakan bahwa pendidikan karakter melalui kegiatan organisasi kemahasiswaan di perguruan tinggi mengisyaratkan bahwa kemampuan manajerial dan sosial mahasiswa yang di dapat ketika berorganisasi harus disertai dengan penanaman moral dan akhlak yang bagus atau karakter unggul dari para pengurusnya. Penelitian ini terkait dengan organisasi mahasiswa, yang lebih memfokuskan kepada implementasi kebijakan Rektor tentang tata krama dan etika mahasiswa di UKM/Ormawa.

Rektor UNP sebagai pembuat kebijakan seharusnya mampu melihat kondisi di lapangan dan menganalisis resiko atau kendala yang akan muncul ketika pelaksanaan kebijakan. Karena suatu kebijakan tidak hanya ditentukan oleh kualitas kebijakan semata, tetapi bagaimana kebijakan itu diimplementasikan dalam bentuk tindakan-tindakan yang mengarah kepada tujuan yang ingin dicapai. George C. Edward III (Riant Nugroho, 2014:673) mengajukan empat faktor/variabel yang berpengaruh terhadap keberhasilan atau kegagalan implementasi kebijakan secara langsung yang saling berinteraksi satu sama lain. Keempat faktor tersebut dapat dijelaskan sebagai berikut:

1. Komunikasi. Untuk mendukung ketercapaian suatu kebijakan, maka setiap tujuan dan sasaran yang ditetapkan dalam kebijakan harus disosialisasikan kepada kelompok sasaran dengan transmisi, kejelasan dan konsistensi. 
2. Sumber Daya. Keberhasilan implementasi kebijakan harus didukung oleh sumberdaya berupa sumberdaya manusia yang memiliki kompetensi implementor dan sumberdaya finansial.

3. Disposisi (Sikap). Keberhasilan implementasi kebijakan tidak hanya ditentukan oleh sejauh mana para pelaku kebijakan mengetahui apa yang harus dilakukan dan mampu melakukannya, tetapi juga ditentukan oleh kemauan para pelaksana untuk melaksanakan kebijakan tersebut.

Struktur Organisasi. pola hubungan kewenangan dan koordinasi antara agen pelaksana (instansi) yang terkait dengan implementasi kebijakan.

\section{METODE}

Penelitian ini menggunakan jenis penelitian kualitatif dengan metode deskriptif untuk mennjelaskan implementasi kebijakan Rektor tentang tata krama dan etika mahasiswa di UKM/Ormawa UNP. Karena jenis penelitian ini kualitatif maka data yang diperoleh haruslah mendalam, jelas dan spesifik.

Pada penelitian ini, peneliti menggunakan teknik pengumpulan data dengan cara observasi, wawancara dan dokumentasi menggunakan instrumen penelitian berupa pedoman wawancara dan studi dokumentasi. Informan dalam penelitian dipilih dengan teknik purposive. Adapun yang menjadi informan dalam penelitian ini yaitu Wakil Rektor III UNP, Wakil Dekan III Fakultas Ilmu Sosial, Kabag. Kemahasiswaan dan Alumni, Kasubbag. Kemahasiswaan MPIK, Pembina UKM, Satpam, BEM dan MPM, beberapa pengurus UKM/Ormawa selingkungan UNP, mahasiswa dan masyarakat yang tinggal disekitar UNP. Pengujian keabsahan data menggunakan triangulasi sumber dan metode dengan teknik analisis data dimulai dari pengumpulan data, reduksi data, penyajian data, dan penarikan kesimpulan.

\section{HASIL DAN PEMBAHASAN}

Ada dua hal yang dibahas dalam hasil temuan dan pembahasan, yaitu: (1) Implementasi kebijakan Rektor tentang tata krama dan etika mahasiswa di UKM/Ormawa UNP; (2) Faktor-faktor yang mempengaruhi ilmplementasi kebijakan Rektor tentang tata krama dan etika mahasiswa di UKM/Ormawa UNP.

\section{Implementasi Kebijakan Rektor tentang Tata Krama dan etika Mahasiswa di UKM/Ormawa UNP}

Berdasarkan hasil temuan peneliti, dapat disimpulkan bahwa implementasi kebijakan Rektor tentang tata krama dan etika mahasiswa di UKM/Ormawa UNP belum terlaksana dengan efektif berdasarkan permasalahan di lapangan, sebagai berikut:

\section{a. Kegiatan mahasiswa di dalam kampus}

Berdasarkan hasil temuan peneliti, tata krama dan etika mahasiswa di UKM/Ormawa UNP sudah terlaksana sebagaimana mestinya yaitu melakukan kegiatan sesuai bidang organisasinya dengan meminta izin terlebih dahulu kepada pembina. Hanya saja dari 20 UKM/Ormawa yang ada, masih ada beberapa UKM yang melakukan kegiatan yang tidak berhubungan dengan organisasi seperti main domino, main gitar dan mengobrol hingga larut malam di PKM. Hal tersebut diperparah dengan tidak adanya pengawasan dari pihak lain seperti satpam atau pembina, yang ada hanya mahasiswa. Jika hal ini dibiarkan tanpa tindak lanjut maka akan timbul penilaian negatif dari orang luar atau masyarakat sekitar. Selain itu, dengan tidak adanya pengawasan maka kemungkinan kehilangan atau pencurian bisa terjadi karena keamanan yang kurang terjaga.

\section{b. Kegiatan mahasiswa di luar kampus}

Berdasarkan temuan peneliti, kegiatan mahasiswa yang diizinkan dan didanai oleh UNP harus mengikuti prosedur perizinan mulai dari membuat program kerja, proposal kegiatan, hingga persiapan yang matang dengan tujuan agar kegiatan mahaiswa yang di lakukan di luar kampus bisa membawa nama baik UNP, hanya saja terkadang dana yang diberikan oleh kampus belum mendukung kelancaran kegiatan mahasiswa di luar kampus sehingga mahasiswa harus berinisiatif mencari dana tambahan untuk mempersiapkan kegiatan tersebut. Selain itu, kegiatan di luar kampus jarang di damping oleh pembina, dan biasanya pembina hanya mendampingi ketika awal kegiatan saja. Namun, hubungan komunikasi antara pihak kemahasiswaan selaku pihak yang membeikan izin dengan mahasiswa terlihat juga cukup intensif dan dekat karena sudah saling mengenal wajah dan nama satu sama lain.

\section{c. Penggunaan gedung PKM dan sekretariat}

Berdasarkan temuan peneliti bahwa kegiatan mahasiswa memang lebih banyak dilakukan pada malam hari tapi tidak bisa dipungkiri masih ada beberapa oknum yang menjadikan sekretariat sebagai tempat tidur. Hal ini terlihat dari adanya kasur yang diletakkan di dalam sekre, tempat tidur yang sengaja dibuat oleh mahasiswa, dan peralatan-peralatan pribadi yang seharusnya tidak boleh diletakkan di dalam sekretariat seperti magic, kompor, peralatan makan, tv, dan sebagainya. Jika dilihat dari segi aturan tentu itu sudah melanggar karena menggunakan fasilitas kampus untuk kepentingan pribadi. Selain itu, penilaian masyarakat sekitar juga akan buruk jika mahasiswa tidur di kampus dan berkegiatan hingga malam hari. Mahasiswa hendaknya harus mampu menjaga nama 
baik UNP agar tidak tercoreng oleh perbuatan satu atau dua orang saja maka mahasiswa harus selalu menjaga etika dan memperhatikan lingkungan sekitar karena kampus UNP terletak ditengah-tengah masyarakat yang erat dengan nilai-nilai sosial.

d. Penggunaan Narkoba, Miras, Judi dan Pergaulan Bebas

Berdasarkan temuan peneliti, memang tidak ada ditemukan kasus-kasus narkoba, miras, judi, dan pergaulan bebas di PKM, hanya saja peneliti mendapati ada dari mahasiswa PKM yang merokok dan main domino tetapi tidak ada unsur judinya, mereka hanya sekedar bermain. Untuk mengantisipasi hal tersebut, satpam selalu melakukan patroli terjadwal dengan menggunakan mobil patroli kampus dari pagi hingga malam. Yang dikhawatirkan dan ditakutkan adalah masih adanya mahasiswa yang duduk-duduk di tempat yang sepi di sudut-sudut kampus yang minim penerangan, maka dari itu perlu pengamanan ekstra dari pihak keamanan kampus untuk mengawasinya. Mahasiswa juga harus memiliki kesadaran yang tinggi terhadap nilai etika dan tata krama yang ada.

e. Keamanan, ketertiban, kebersihan dan keindahan sekretariat

Berdasarkan temuan peneliti, keamanan, ketertiban, kebersihan dan keindahan masing-masing sekre UKM sudah terjaga namun untuk gedung PKM secara keseluruhan belum. Hal ini sesuai dengan hasil observasi dilapangan, kebanyakan UKM bersifat individual dalam hal menjaga ketertiban, keamanan, dan keindahan sekretariatnya sehingga mereka terlihat tidak terlalu peduli dengan fasilitas yang ada di gedung PKM. Meskipun sudah ada cleaning service yang membersihkan PKM tetapi tetap saja penampilan gedung PKM tampak berantakan. Selain itu, Dalam hal keamanan di gedung PKM masih kurang karena tidak ada satpam yang standby dan cctv disana sehingga mahasiswa harus menjaga keamanan sekrenya masing-masing, dan hal ini juga lah yang menjadi alasan mahasiswa menginap di sekre. Namun hal positifnya adalah semua unit kegiatan yang ada di PKM saling mengenal satu sama lain. Mereka selalu berjabat tangan dan menyapa anggota yang berada di dalam sekre, dan hal ini menjadi salah satu bentuk etika dan tata krama yang selalu mereka budayakan. Seluruh UKM/Ormawa juga memiliki tata tertib dan daftar piket yang di pajang di dinding sekre dan untuk menunjang keindahan sekre mereka memajang benda-benda berharga seperti piagam penghargaan, struktur organisasi, maupun karya seni lain yang dirasa bagus. Namun, ada fasilitas di PKM yang sudah rusak seperti WC yang tersumbat dan dinding yang dicoret padahal gedung tersebut masih baru dipakai.

\section{f. Penerapan sanksi bagi yang melanggar}

Berdasarkan temuan peneliti, jika pelanggaran masih dalam lingkup akademik, etika dan moral, pemberian sanksi dan penyelesaiannya dilakukan oleh UNP yang menyelesaikan, seperti tindakan asusila yang tertangkap oleh satpam maka akan dikenakan sanksi akademik dengan menasehati dan membinanya terlebih dahulu dan dipanggil orang tuanya serta ditanya apa tujuannya kuliah. Tapi jika pelanggarannya berat maka akan langsung dibawa ke aparat kepolisian, seperti narkoba, mabuk-mabukan, atau merusak aset Negara dan nama UNP.

Faktor-Faktor yang mempengaruhi Implementasi Kebijakan Rektor tentang Tata Krama dan Etika Mahasiswa di UKM/Ormawa UNP

Berdasarkan hasil temuan peneliti mengenai implementasi kebijakan Rektor tentang tata krama dan etika mahasiswa di UKM/Ormawa UNP melalui Surat Edaran No.3916/UN35/KM/2017 maka dapat dipahami bahwa kebijakan tersebut memang sesuatu yang dibutuhkan mahasiswa khususnya organisasi mahasiswa sebagai acuan dalam bertindak, namun hal ini memang belum terlaksana sebagaimana mestinya karena masih ada beberapa point dalam SE yang masih belum berjalan. Adapun faktor-faktor yang mempengaruhi implementasi kebijakan Rektor tentang tata krama dan etika mahasiswa di UKM/Ormawa UNP secara garis besar dapat dapat diidentifikasi sebagai berikut:

1) Komunikasi

\section{a. Adanya sosialisasi yang dilakukan terkait surat edaran Rektor}

Berdasarkan temuan peneliti, sosialisasi yang dilakukan Rektor terkait surat edaran tersebut sudah ada dan mendukung implemetasi kebijakan rektor tentang tata krama dan etika mahasiswa di UKM/Ormawa UNP baik dalam bentuk tertulis seperti memasang spanduk besar di pintu masuk PKM dan maupun diskusi seperti mengadakan rapat yang dihadiri oleh beberapa unsur terkait. Hanya saja masih ada penolakan-penolakan dari mahasiswa terkait kebijakan Rektor tersebut yang berargumen bahwa kebijakan tersebut membatasi ruang gerak mahasiswa sebagai salah satu unit kegiatan.

\section{b. Masih rendahnya pemahaman mahasiswa terhadap isi kebijakan}

Berdasarkan temuan peneliti, pemahaman mahasiswa bahwa aturan tersebut membatasi kegiatan dan kreativitas mahasiswa sebenarnya keliru. Aturan tersebut bukan untuk membatasi kegiatan mahasiswa melainkan untuk mengontrol agar kegiatan mahasiswa berjalan tertib. Kesadaran dan pemahaman mahasiswa terhadap isi dan maksud dari kebijakan masih kurang dan cenderung tidak begitu peduli, sehingga mahaisswa banyak yang kontra 
dan tidak mau melaksanakan aturan tersebut dengan anggapan bahwa surat itu tidak efektif dilaksanakan. Selain itu, karena tidak adanya kepedulian, mahasiswa tetap melaksanakan kegiatan seperti biasa dan tidak menganggap sebuah pelanggaran sebagai kesalahan.

\section{c. Pelaksanaan kebijakan belum konsisten}

Berdasarkan temuan peneliti, pelaksana kebijakan tidak menerapkan aturan ini dengan konsisten seperti tidak konsisten dalam pemberian sanksi bagi yang melanggar kebijakan tersebut. Sanksi yang ada berdasarkan SE No.3916/UN35/KM/2017 tentang tata krama dan etika mahasiswa di UKM/Ormawa UNP pada point 6 , hanya berupa sanksi akademik, dalam pratiknya pun tidak dilaksanakan sanksi tersebut. Sanksi hanya belaku bagi pelanggaran yang berat seperti narkoba, miras, judi dan pergaulan bebas, tapi untuk pelanggaran yang bersifat ringan seperti menjadikan sekre tempat tidur, merusak fasiltas kampus, tidak menjaga kebersihan sekre dan lain-lain sanksinya kurang tegas.

\section{2) Sumber Daya}

\section{a. Kurangnya kepedulian mahasiswa dalam menjaga kebersihan dan keindahan PKM}

Berdasarkan temuan peneliti, mahasiswa kurang peduli terhadap kebersihan dan keindahan di lingkungan PKM dan hanya memprioritaskan kebersihan dan keindahan masing-masing sekretariat saja. Penampilan gedung PKM terlihat berantakan dan tidak terjaga kebersihannya. Mereka cenderung hanya membersihkan sekretariatnya saja sehingga tidak memperdulikan keadaan lingkungan PKM. bahkan ada mahasiswa yang mencoret dinding PKM dengan tulisan dan lukisan. Dari segi aturan tentu sudah melanggar karena termasuk dalam pelanggaran merusak fasilitas kampus.

\section{b. Sarana dan prasarana di PKM belum sepenuhnya menunjang kelancaran kegiatan mahahasiswa}

Berdasarkan temuan peneliti, meskipun gedung PKM baru digunakan, namun fasilitas dan sarana prasarana yang ada masih belum menunjang sepenuhnya kelancaran kegiatan mahasiswa di PKM sehingga mahasiswa berinisiatif sendiri melengkapi sarana dan prasarana yang belum ada seperti dengan menggunakan iuran anggota dan bantuan dari alumni-alumni karena fasilitas dari UNP memang beberapa sudah tidak layak pakai lagi dan kebanyakan barang-barang dari sekre berasal dari anggota.

\section{3) Disposisi (Sikap)}

\section{a. Tidak adanya kemauan mahasiswa untuk mematuhi kebijakan Rektor}

Berdasarkan temuan peneliti, meskipun aturan itu sudah ada dan pada prinsipnya tidak membatasi kegiatan mahasiswa, namun mahasiswa tidak mau mematuhinya. Dari enam point yang diatur dalam SE Rektor tersebut, hanya bebapa saja yang benar-benar dipatuhi oleh mahasiswa seperti tidak terlibat narkoba, miras, judi dan pergaulan bebas, serta keamanan, ketertiban, kebersihan dan keindahan sekre yang menjadi tanggung jawab masing-masing UKM/Ormawa. Tetapi dalam hal penggunaan gedung PKM dan sekretariat masih ada mahsiswa yang tidak mematuhinya dan menjadikan sekre sebagai tempat tidur. Selain itu, mahasiswa yang masih berada di kampus hingga dini hari tanpa kegiatan yang jelas juga mengindikasi bahwa mahasiswa memang tidak mau mematuhi kebijakan rektor tersenut sehingga faktor ketidaukmauan mahasiswa juga menjadi faktor penghambat dalam implementasi kebijakan Rektor tentang tata krama dan etika mahasiswa di UKM/Ormawa UNP.

b. Masih kurangnya pengawasan dari Rektor dan pihak terkait lainnya

Pengawasan merupakan komponen penting dalam mengimplementasikan suatu kebijakan agar kebjakan tersebut berjalan dengan semestinya. Namun, kebijakan tersebut belum terlaksana secara sepenuhnya, karena memang dari pihak terkait jarang melakukan pengawasan di lapangan atas kebijakan yang dikeluarkan tersebut. Sesuai dengan hasil observasi dan catatan di lapangan, pengawasan dari pihak kampus dalam bentuk sidak memang pernah dilakukan walaupun jarang, tetapi untuk pengawasan yang bersifat menetap di PKM sampai saat ini belum ada. Tidak ada dari pihak kampus yang mengawasi secara penuh kegiatan mahasiswa di PKM.

\section{4) Struktur Organisasi}

Adanya SOP kegiatan kemahasiswaan di dalam maupun di luar kampus

Berdasarkan temuan peneliti, kegiatan mahasiswa pada umumnya harus melewati prosedur perizinan terlebih dahulu dan dipertimbangkan apakah kegiatan tersebut bermanfaat atau tidak bagi kemajuan UNP. Hal ini sesuai dengan hasil observasi di lapangan dan catatan dokumentasi, bahwa mahasiswa yang mengikuti UKM/Ormawa pada umumnya memiliki program kerja yang setiap tahunnya di rancang dan disusun bersamaan dengan ADRT. Bagi pengurus UKM/Ormawa dan panitia yang ditunjuk sebagai panitia acara yang akan diadakan wajib membuat proposal dan mengurus izin kegiatan terlebih dahulu di bagian kemahasiswaan yang ada di gedung Rektorat UNP.

\section{PENUTUP}

\section{Simpulan}

Berdasarkan hasil temuan dan pembahasan pada penelitian ini, dapat di tarik kesimpulan bahwa implementasi kebijakan rektor tentang tata krama dan etika mahasiswa di UKM/Ormawa UNP belum berjalan 
sebagaimana mestinya. Meskipun sudah ada aturan pelaksana yang dikeluarkan oleh Wakil Rektor III tersebut namun masih ada beberapa point dalam SE tersebut yang tidak terlaksana seperti masih ada mahasiswa yang berada di PKM hingga malam hari tanpa ada kegiatan yang jelas, kegiatan di dalam maupun diluar kampus yang jarang didampingi pembina, kantor sekretariat yang dijadikan tempat tidur, keamanan, kebersihan, keindahan PKM yang masih belum terjaga dan sanksi yang kurang tegas bagi mahasiswa yang melanggar aturan. Jika dikaitkan dengan 4 faktor yang mempengaruhi implementasi kebijakan menurut teori Edward III maka faktor komunikasi seperti adanya sosialisasi yang dilakukan Rektor dan struktur organisasi seperti adanya SOP kegiatan kemahasiswaan di dalam maupun di luar kampus telah mendukung implementasi kebijakan Rektor tersebut, sedangkan faktor komunikasi seperti masih rendahnya pemahaman mahasiswa terhadap isi kebijakan, pelaksanaan kebiajakn belum konsisten, faktor sumber daya seperti kurngnya kepedulian mahasiswa dalam menjaga kebersihan dan keindahan PKM, sarana dan prasarana di PKM belum sepenuhnya menunjang kelancaran kegiatan mahasiswa, dan faktor disposisi (sikap) seperti tidak adanya dan masih kurangnya pengawasan dari Rektor dan pihak terkait lainnya menjadi faktor penghambat dalam pelaksanaan kebijakan Rektor tentang Tata Krama dan Etika Mahasiswa di UKM/Ormawa UNP. Adapun kendala yang ditemui yaitu masih rendahnya pemahaman dan kesadaran mahasiswa terhadap isi kebijakan, sarana dan prasarana yang ada masih kurang memadai, kurang tegasnya sanksi yang diberikan kepada para pelanggar dan masih kurangnya pengawasan dari Rektor dan pihak terkait lainnya.

\section{Saran}

Dari apa yang telah dijelaskan, penulis mengemukakan beberapa saran sebagai berikut: Pertama, diharapakan kepada Rektor UNP agar dapat selalu menjaga keharmonisan dalam hal komunikasi, kerjasama dan koordinasi antara pihak rektorat dengan pihak terkait lainnya dengan cara selalu melakukan komunikasi di setiap kebijakan, sering melakukan pengawasan di lapangan terkait peaksanaan kebijakan, dan meningkatkan fasilitas yang menunjang kelancaran kegiatan mahasiswa Untuk melaksanakan kebijakan ini dengan tegas maka SE tersebut hendaknya dibuat dalam bentuk aturan yang lebih mengikat dengan sanksi yang lebih tegas. Kedua, diharapkan kepada mahasiswa agar peka terhadap suatu kebijakan, jika tampak sebuah pelanggaran maka laporkan agar Rektor dan pihak terkait lainnya dapat menindaklanjuti segala pelanggaran yang ada. Mahasiswa UKM harus membuat program kerja yang jelas dan selalu meminta izin dan berkoordinasi dengan pembina dan satpam setiap ada kegiatan yang akan dilakukan serta bisa mengatur waktu sebaik mungkin antara kuliah dengan organisasi agar tetap terjaga keseimbangannya.

\section{DAFTAR PUSTAKA}

Cahyaning, Mustika Pertiwi,dkk. 2014. Hubungan Organisasi dengan Mahasiswa dalam Menciptakan Leadership. Aktualisasi Bimbingan dan Konseling pada Pendidikan Dasar Menuju Peserta Didik yang Berkarakter. Prosiding Seminar Nasional dan Call for Papers.

Kepmendikbud RI No.155/U/1998 tentang Pedoman Umum Organisasi Kemahasiswaan di Perguruan Tinggi.

Keputusan Rektor No.55/J.41/KM/2004 tentang Petunjuk Teknis Organisasi Kemahasiswaan UNP.

Nugroho, Riant. 2003. Kebijakan Publik, Formulasi, Implementasi dan Kebijakan. Jakarta: Gramedia.

Peraturan Menteri Riset, Teknologi, dan Pendidikan Tinggi No. 67 Tahun 2016 tentang Statuta Universitas Negeri Padang.

Ridwan, Muhammad Siregar, dkk. 2016. Implementasi Good Governance pada Organisasi Mahasiswa di Universitas Gadjah Mada Demi Mewujudkan Good Student Governance. Jurnal Penelitian Hukum Volume 3, Nomor 1, Maret 2016, Halaman 56-69.

Sugiyono. 2008. Metode penelitian pendidikan. Bandung: Alfabeta.

Surat Edaran Kementerian Riset, Teknologi dan Pendidikan Tinggi No.106/B/SE/2017 tentang Pembinaan Kegiatan Kemahasiswaan.

Surat Edaran Rektor UNP No.154/UN35/KM/2017 tentang Tata Krama dan Etika Mahasiswa di UKM/Ormawa

Surat Keputusan Rektor No. 146/H35/KP/2004 tentang Kode Etik Mahasiswa UNP.

Suroto. 2016. Dinamika Kegiatan Organisasi Kemahasiswaan Berbasis Kearifan Lokal Dalam Upaya Memperkuat Karakter Unggul Generasi Muda. Jurnal Pendidikan Kewarganegaraan: Volume 6, Nomor 2, Nopember 2016.

Tim Revisi. 2014. Buku Panduan Kegiatan Kemahasiswaan 2014-2015. Universitas Negeri Padang.

Undang-Undang Nomor 12 Tahun 2012 tentang Pendidikan Tinggi.

www.UNPku.com.ganto/docs/edisi_191_ok 